\title{
Chapter 41 \\ Electrochemical Sensors for the Detection of Hydrogen Prepared by PLD and Sol-Gel Chemistry
}

\author{
George A. Mousdis, M. Kompitsas, and I. Fasaki
}

\begin{abstract}
Two different series of $\mathrm{H}_{2}$ sensors were prepared. The first series was based on n-type semiconducting $\mathrm{SnO} 2$ thin films, prepared by the sol-gel method. The effect of $\mathrm{Au}$ and $\mathrm{Pt}$ nanoparticles in $\mathrm{SnO}_{2}$ was investigated for gas sensor applications. The second series was based on p-type $\mathrm{NiO}$ thin films, which were grown by pulsed laser deposition on microscope glass or (100) Si substrates. The effect of substrate temperature and $\mathrm{O}_{2}$ pressure during the deposition process on the morphological and sensing properties of the films has been investigated. The films were fully characterized. A significant response to a broad range of hydrogen concentrations was demonstrated for both series of films at operating temperatures lower than $200^{\circ} \mathrm{C}$.
\end{abstract}

Keywords $\mathrm{SnO}_{2} \cdot \mathrm{NIO} \cdot$ Thin films $\cdot \mathrm{Au} \cdot \mathrm{Pt}$ nanoparticles $\cdot$ Hydrogen sensor

\section{Introduction}

Nowadays the development of solid-state gas sensors for the detection of inflammable and toxic gases such as hydrogen, carbon monoxide, etc. is a major concern for both human and environmental protection.

Hydrogen is an abundant, renewable, efficient, clean energy source, which produces zero emissions [1]. In the near future it could be used as a city gas or to power cars in the same way as natural gas is used. As an industrial gas, it is currently used in a large number of areas, e.g. chemistry (crude oil refining, plastics, as a reducing environment in float glass industry, etc.), food products (hydrogenation of oils and fats), semiconductors (as a processing gas in thin film deposition and annealing atmospheres), and transportation (as fuel in fuel cells and space vehicle rockets).

All these applications require the development of hydrogen sensing devices that allow safe control of the gas usage. Devices capable of detecting hydrogen

\footnotetext{
G.A. Mousdis ( $\square)$, M. Kompitsas, and I. Fasaki

Theoretical and Physical Chemistry Institute-TPC, INHRF-National Hellenic

Research Foundation, 48 Vassileos Constantinou Avenue, Athens 11635, Greece

e-mail: gmousdis@eie.gr
} 
concentrations below the lowest explosion limit (LEL) of 40,000 ppm [2] have become indispensable to prevent explosions. A promising approach in the field of solid-state sensing devices is to use electrochemical gas sensors based on semiconducting metal oxides (MO), utilizing novel gas sensing materials [3].

Metal oxides, in particular tin dioxide, are widely used as a basic material for the preparation of gas sensing devices [4]. The effect of the addition of metallic particles on the gas sensing properties of metal oxides has been widely studied, but the results depend on the experimental conditions and method of fabrication [5]. Although n-type transition metal oxide semiconductors (such as $\mathrm{SnO}_{2}$ and $\mathrm{ZnO}$ ) have already been investigated as gas-sensing materials, the sensing properties of p-type semiconducting oxides have received significantly less attention.

Nickel oxide $(\mathrm{NiO})$ is widely considered as a model p-type semiconductor. Due to its excellent chemical stability, $\mathrm{NiO}$ films have a broad range of applications as catalysts [6], electrochromic display devices [7] and fuel cells [8]. Moreover, recent studies have shown that $\mathrm{NiO}$ thin films are attractive sensing materials in gas and humidity detection devices [9].

MO thin films can be deposited by different techniques, including chemical selfassembling, sol-gel, rf sputtering, dc sputtering and pulsed laser deposition (PLD). We have used an alkoxide sol-gel method to prepare $\mathrm{SnO}_{2}$ thin films, undoped or doped with $\mathrm{Au}$ and $\mathrm{Pt}$ nanoparticles. Additionally, undoped $\mathrm{NiO}$ thin films were prepared by PLD. All films prepared were tested as $\mathrm{H}_{2}$ sensors, and the influence of preparation conditions to the sensing properties were studied.

\section{Experimental}

\section{Synthesis of $\mathrm{SnO}_{2}$ Films}

Starting point was a mixture of tin isopropoxide in isopropanol and an ethanolic solution of $\mathrm{HAuCl}_{4}$ (or $\mathrm{H}_{2} \mathrm{PtCl}_{6}$ ) [10]. This solution was hydrolyzed and aged by stirring at room temperature (r.t.) for $24 \mathrm{~h}$. After spin-coating on glass or Si substrates, the tin oxide gel films were dried at r.t. for 1 day and heat-treated for $2 \mathrm{~h}$ at $510^{\circ} \mathrm{C}$ in air. The content of the metals ( $\mathrm{Au}$ and $\mathrm{Pt}$ ) in the $\mathrm{SnO}_{2}$ matrix was $5 \mathrm{wt} \%$.

\section{Synthesis of NiO Films}

Undoped $\mathrm{NiO}$ films were grown by PLD in a stainless steel vacuum chamber [11]. A Ni foil (purity 99.999\%) was used as a target, placed on a movable vacuumcompatible, computer-controlled XY translator and irradiated by a Quantel Nd: YAG laser $(\lambda=355 \mathrm{~nm})$ at a repetition rate of $10 \mathrm{~Hz}$. The $\mathrm{NiO}$ films were 
deposited on heated Si or glass substrates. Two series of films were grown. The first was deposited at an $\mathrm{O}_{2}$ pressure of $10 \mathrm{~Pa}$ at room temperature, $200^{\circ} \mathrm{C}$ and $400^{\circ} \mathrm{C}$, the second at $400^{\circ} \mathrm{C}$ and $\mathrm{O}_{2}$ pressures ranging from 5 to $50 \mathrm{~Pa}$.

\section{Characterization and Sensing Studies}

The films were characterized by thermogravimetric analysis (TGA), scanning electron microscopy (SEM), X-ray diffraction (XRD) and ellipsometry.

Hydrogen sensing tests were performed in an aluminum vacuum chamber [12]. The chamber was evacuated down to $1 \mathrm{~Pa}$, filled with dry air at atmospheric pressure. The samples were resistively heated to operating temperatures of $147-180^{\circ} \mathrm{C}$. The films were tested at hydrogen concentrations in the range of 10,000-500 ppm. The hydrogen concentration was calculated based on the partial pressures of the sensed gas and air inside the chamber. A bias of $1 \mathrm{~V}$ was applied, and the current through the film was measured with a Keithley Mo. 485 Picoammeter. The response $r$ is defined as $r=\left(R_{o}-R_{s}\right) / R_{o}=\left(I_{s}-I_{0}\right) / I_{0}$, where $R_{s}$ and $R_{o}$ are the sensor resistivities with and without gas, respectively. Current changes are therefore a measure for hydrogen sensing.

\section{Results and Discussion}

\section{$\mathrm{SnO}_{2}$ Films}

\section{Structural and Morphological Properties}

Thermogravimetric analysis showed that heating at $500^{\circ} \mathrm{C}$ evaporates or burns all the organic components and reduces the $\mathrm{HAuCl}_{4}$ or $\mathrm{H}_{2} \mathrm{PtCl}_{6}$ to metallic $\mathrm{Au}$ or $\mathrm{Pt}$. XRD characterization of the films revealed that both types of $\mathrm{SnO}_{2}$ samples are polycrystalline. The presence of $\mathrm{Au}$ and Pt clusters in the films seems to induce some changes in the texture of the films [10]. $\mathrm{SnO}_{2}-\mathrm{Au}$ films have a clear tendency of texturing in the [101] and [200] crystalline directions of the tetragonal rutile structure. $\mathrm{SnO}_{2}-\mathrm{Pt}$ films show a weaker tendency for texturing with a preferred orientation towards the [200] direction [10].

According to scanning electron microscopy (SEM) characterization, all $\mathrm{SnO}_{2}$ samples show the presence of a granular film structure with randomly distributed and shaped particles on the surface. In the case of the $\mathrm{SnO}_{2}-\mathrm{Au}$ sample, the particles are mostly irregularly shaped with dimensions of a few hundred nanometers, as shown in Fig. 41.1 (ignoring some quite big features of $\mu \mathrm{m}$ dimensions attributed to dust formation and impurities during sample preparation for SEM). In the case of $\mathrm{SnO}_{2}-\mathrm{Pt}$, the top features are clearly hexagonal faceted (Fig. 41.1. insert). 

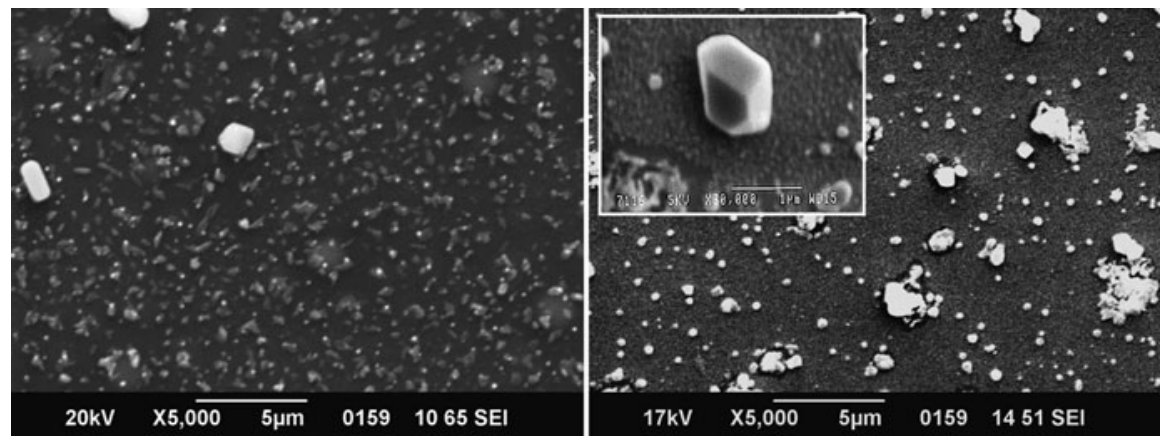

Fig. 41.1 SEM image of $\mathrm{SnO}_{2}-\mathrm{Au}(l e f t)$ and $\mathrm{SnO}_{2}-\mathrm{Pt}($ right $)$ thin films
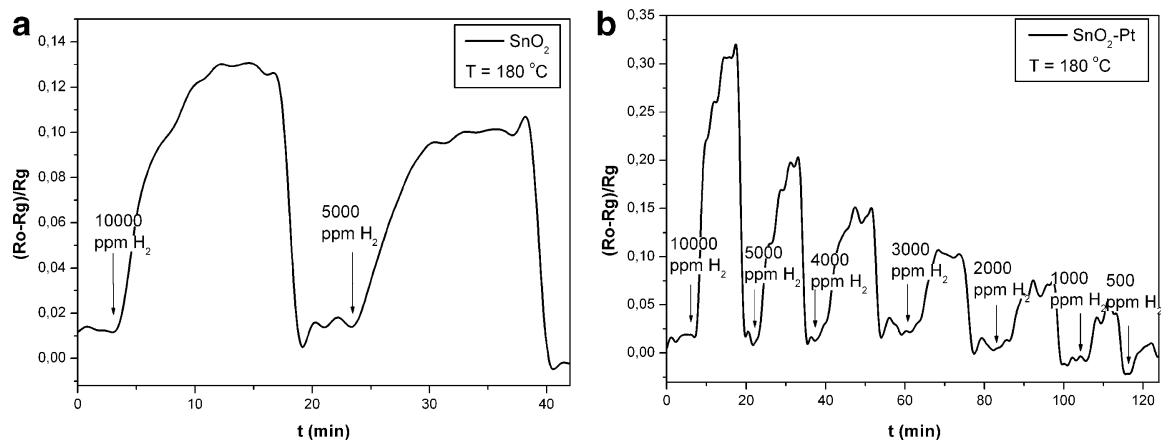

Fig. 41.2 Response of $\mathrm{SnO}_{2}$ and $\mathrm{Pt}-\mathrm{SnO}_{2}$ thin films at $180^{\circ} \mathrm{C}$

\section{Hydrogen Sensing}

$\mathrm{SnO}_{2}$ films without metal nanoparticles respond only at temperatures above $180^{\circ} \mathrm{C}$ and hydrogen concentrations higher than 5,000 ppm (Fig. 41.2a). The presence of Pt in modified $\mathrm{SnO}_{2}-\mathrm{Pt}$ films distinctly enhanced the relative response, the detection limit was lowered down to $500 \mathrm{ppm}$ (Fig. 41.2b). The $\mathrm{SnO}_{2}-\mathrm{Au}$ sensor response exhibits a dramatic increase by 50 times at the same temperature (Fig. 41.3a). Furthermore the working temperature can be lowered down to $85^{\circ} \mathrm{C}$ (Fig. $41.3 \mathrm{~b}$ ).

\section{NiO Films}

\section{Structural and Morphological Properties}

XRD analysis of the samples prepared at r.t., $200^{\circ} \mathrm{C}$ and $400^{\circ} \mathrm{C}$ showed that the film deposited at r.t. is poorly crystallized. When increasing the substrate temperature, the $\mathrm{NiO}$ lines become narrower and their intensities increase, indicative of an 

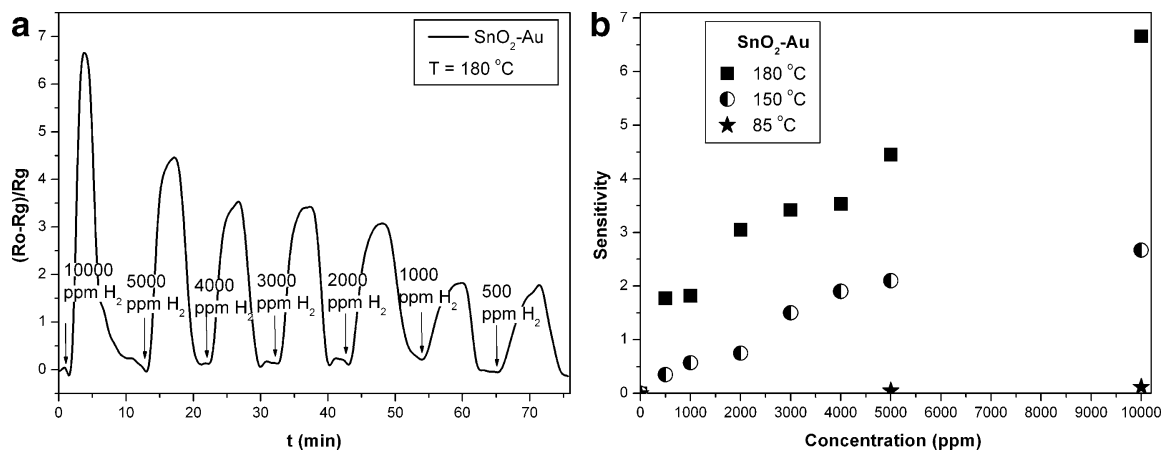

Fig. 41.3 (a) Response of $\mathrm{Au}-\mathrm{SnO}_{2}$ thin films at $180^{\circ} \mathrm{C}$ for $10,000-500 \mathrm{ppm} \mathrm{H}_{2}$; (b) at different temperatures for $10,000 \mathrm{ppm}_{2}$
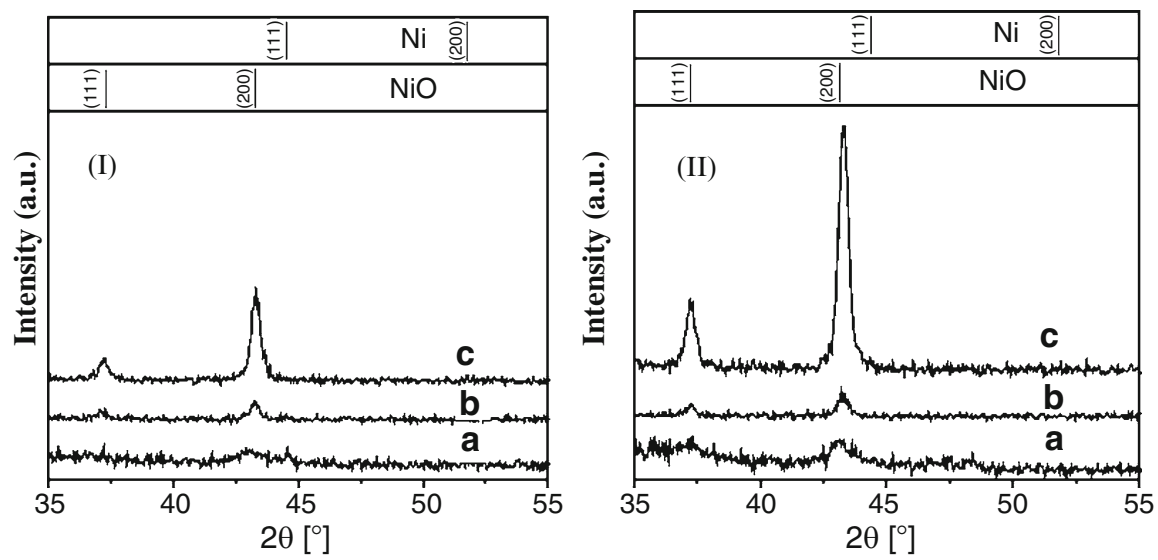

Fig. 41.4 X-ray diffractograms of $\mathrm{NiO}$ thin films grown on $\mathrm{Si}$ at r.t. (a), at 200 (b) and $400^{\circ} \mathrm{C}(\mathbf{c})$; (I) without postdeposition heat treatment; (II) after post-deposition heat treatment at $500^{\circ} \mathrm{C}$ for $3 \mathrm{~h}$

improved crystallinity (Fig. 41.4I). Annealing at $500^{\circ} \mathrm{C}$ for $3 \mathrm{~h}$ increases the crystallinity mainly for the films prepared at $400^{\circ} \mathrm{C}$ (Fig. 41.4II). Similar results were obtained by AFM.

Ellipsometric measurements of the $\mathrm{NiO}$ films prepared at $400^{\circ} \mathrm{C}$ at different $\mathrm{O}_{2}$ pressures showed that by increasing $\mathrm{p}_{\mathrm{O} 2}$ the thickness of the film decreases while the roughness increases (Fig. 41.5a). SEM images showed that at low $\mathrm{p}_{\mathrm{O} 2} \mathrm{Ni}$ nanoparticles are present due to an incomplete reaction of $\mathrm{Ni}$ with $\mathrm{O}_{2}$ (Fig. 41.5b).

\section{Hydrogen Sensing}

All films responded to the presence of $\mathrm{H}_{2}$ at $180^{\circ} \mathrm{C}$. The response of the first group of $\mathrm{NiO}$ films depends strongly on the preparation temperature (Fig. 41.6a). The best response was observed for the samples prepared at $400^{\circ} \mathrm{C}$ (Fig. 41.6a). According to 

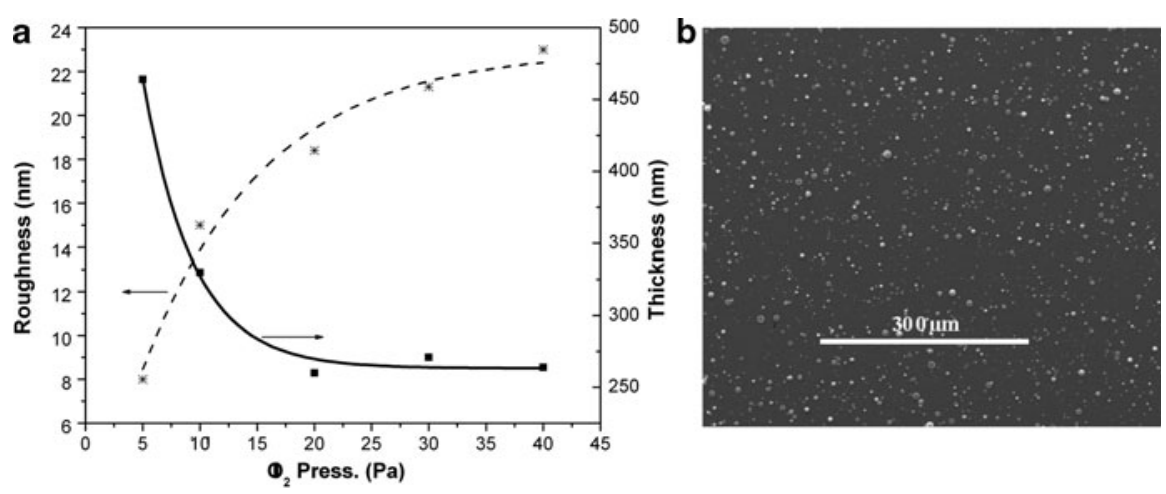

Fig. 41.5 (a) Plot of roughness and thickness of $\mathrm{NiO}$ films as a function $\mathrm{p}_{\mathrm{O} 2}$; (b) SEM image of a $\mathrm{NiO}$ film prepared at $5 \mathrm{~Pa} \mathrm{O}_{2}$ pressure
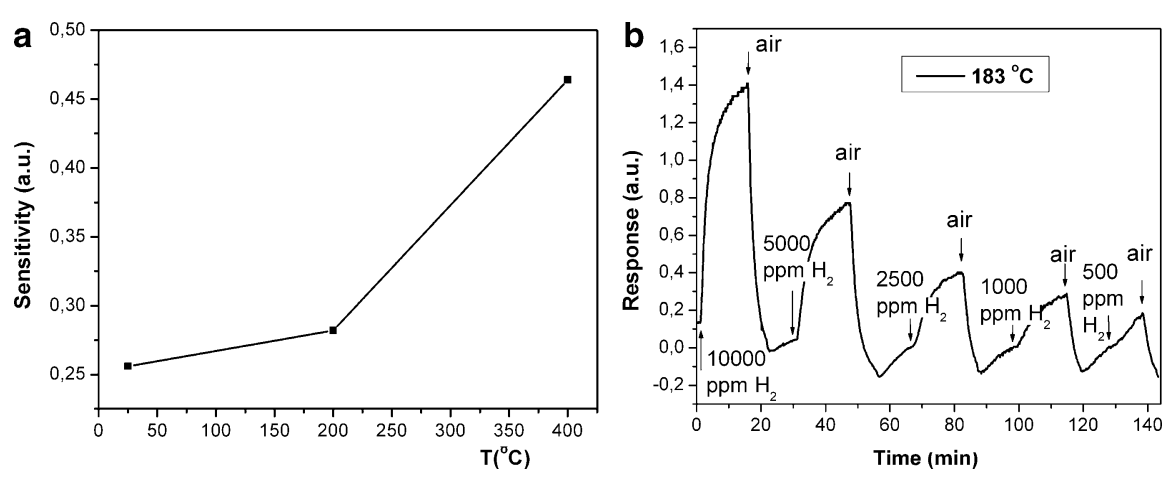

Fig. 41.6 (a) Response of $\mathrm{NiO}$ thin films at $180^{\circ} \mathrm{C}$ to $10,000 \mathrm{ppm} \mathrm{H}_{2}$ as a function of the preparation temperatures; (b) Response of $\mathrm{NiO}$ thin films prepared at $400^{\circ} \mathrm{C}$ and $40 \mathrm{~Pa}_{2}$ pressure at $180^{\circ} \mathrm{C}$ operation temperature to $10,000-500 \mathrm{ppm} \mathrm{H}_{2}$

previous result and the structural and morphological studies of the second group the best sensor was deposited at $400^{\circ} \mathrm{C}$ and $40 \mathrm{~Pa} \mathrm{O}_{2}$ pressure. This film showed a very good linear response at $180^{\circ} \mathrm{C}$ for $\mathrm{H}_{2}$ concentrations of $10,000-500 \mathrm{ppm}$.

\section{Conclusions}

The introduction of $\mathrm{Au}$ and $\mathrm{Pt}$ nanoparticles in $\mathrm{SnO}_{2}$ thin films increase their $\mathrm{H}_{2}$ sensing properties. In particular, Au nanoparticles decrease the working temperature of the sensor to $85^{\circ} \mathrm{C}$ while the response increases more than 50 times. $\mathrm{NiO}$ thin films can also be used as $\mathrm{H}_{2}$ sensors. Their sensing properties, crystallinity and morphology strongly depend on the growth conditions. Optimized sensing properties can be achieved by deposition at $400^{\circ} \mathrm{C}$ and $50 \mathrm{~Pa} \mathrm{O}_{2}$ pressure. 


\section{References}

1. I. Hotovy, J. Huran, P. Siciliano, S. Capone, L. Spiess, V. Rehacek, Sens. Actuators B 103, 300 (2004).

2. Fuel Cell Standards Committee, Basic consideration for safety of hydrogen systems. Technical report ISO TC 197 N166, International Standards Organization, 2001.

3. E. Comini, Anal. Chim. Acta 568, 28 (2006).

4. G.J. Li and S. Kawi, Mater. Lett. 34, 99 (1998).

5. A. Cabot, J. Arbiol, J.R. Morante, U. Weimar, N. Bârsan, W. Göpel, Sensor. Actuat. B: 70, 87 (2000).

6. M. Blaumer and H.J. Freund, Prog. Surf. Sci. 61, 127 (1999).

7. Z. Jiao, M. Wu, Z. Qin, H. Xu, Nanotechnology 14, 458 (2003).

8. X. Chen, N.J. Wu, L. Smith, A. Ignatiev, Appl. Phys. Lett. 84, 2700 (2004).

9. J. Shi, Y. Zhu, X. Zhang, W.R.G. Baeyens, A.M. Garca-Campaña, Trends Anal. Chem. 23, 1 (2004).

10. I. Fasaki, M. Suchea, G. Mousdis, G. Kiriakidis, M. Kompitsas Thin Solid Films 518, 1109 (2009).

11. I. Fasaki, A. Giannoudakos, M. Stamataki, M. Kompitsas, E. György, I.N. Mihailescu, F. Roubani-Kalantzopoulou, A. Lagoyannis, S. Harissopulos, Appl. Phys. A 91, 487 (2008).

12. I. Fasaki, PhD. Thesis University of Athens (2010). 